\title{
Listy miłosne między szlachcicem a jego siostrą, 64 lata przed Klaryssą, w odniesieniu do rodzącego się gatunku angielskiej powieści
}

\author{
Love-Letters Between a Nobleman and His Sister, 64 Years Before Clarissa, and the Nascent \\ Genre of the English Novel
}

\section{Resumen:}

Este trabajo aborda la obra epistolar de Aphra Behn titulada Love-Letters between a Nobleman and his Sister, junto a algunos de sus antecedentes, recalcaldo su valor pionero en lo que atafie a la datacion y en lo que concierte a su contenido. Se plantean unas notas tematicas estudiando el contenido socio-politico de la ficcion y esclareciendo su significado a la luz de la naciente polarization politica entre los Whigs y los Tories. Asimismo se plantean algunas ideas sobre el genero literario deduciendo el valor fundacional de Love-Letters en la tradicion de la novela inglesa asi como el valor desmitificador en cuanto a la tradicion del romance fantasioso. En cuanto al estilo, se infiere que Behn aplica el ideario de transparencia y de claridad predicado por pensadores como Bacon, Locke o Hobbes, y defendido por literatos como Beaumont o Cowley.

\section{Streszczenie:}

Artykuł ten skupia się zarówno na epistolarnym utworze autorstwa Aphry Behna zatytułowanym Listy miłosne miedzy szlachcicem a jego siostrą, jak i jego prekursorach. Wartość omawianego dzieła jest nie do przecenienia, gdyż może ono być postrzegane jako przełomowe jak na czasy, w których powstało, pod względem zawartym w nim treści. Autor dokonuje pewnych tematycznych obserwacji, wnikliwie studiując społeczno-polityczną zawartość omawianej pracy i jednocześnie tłumacząc jej znaczenie w kontekście pączkującej politycznej polaryzacji pomiędzy Wigami a Torysami. Poza tym artykuł podkreśla również fundamentalną rolę Listów miłosnych w procesie obalania tradycji powieści romantycznej typu fantasy. Odnosząc się do stylu pisania, autor zwraca uwagę na sposób, w jaki Behn stosuje zasady przejrzystości i jasności zaproponowane wcześniej przez takich myślicieli jak Bacon, Locke czy Hobbes, a następnie wykorzystywane przez takich pisarzy jak Beaumont czy Cowley.

\section{Abstract:}

This work examines Aphra Behn's epistolary work entitled Love-Letters Between a Nobleman and His Sister, along with some of its precursors, stressing its value as a groundbreaking work, both chronologically and in terms of its content. Some thematic observations are tackled, studying the socio- 
political content of the fictional work and clarifying its meaning in the context of the burgeoning political polarisation between the Whigs and Tories during the era. Some ideas are addressed about the literary genre, establishing the foundational value oi Love-Letters in the tradition of the English novel and its role in overturning the tradition of the fantastic romance. With reference to style, it notes how Behn applies the ideas of transparency and clarity advanced by thinkers like Bacon, Locke and Hobbes, and espoused by writers like Beaumont and Cowley.

\section{Słowa kluczowe:}

Behn, listy miłosne, powieść epistolarna, Monmouth, literatura polityczna

Keywords: Behn, Love-Letters, Epistolary Novel, Monmouth, Political Literature

\section{Palabras clave:}

Behn, Love-Letters, Epistolary Novel, Monmouth, literature politica

\section{l.Introduccion}

El genero de la novela epistolar tiene un punto de partida en Aphra Behn, concretamente en los afios 1684, 1685 y 1687, cuando publico las tres entregas de Love-Letters between a Nobleman and his Sister. El presente estudio considera el valor sefiero de la obra de la escritora inglesa de la Restauracion, que antecede a los afamados trabajos de Richardon, Montesquieu, Lacros, Goethe o Holderlin.

La narrativa de Behn esta en el corolario fundacional de la tradition fictional sobre el adulterio y tambien esta en el semillero de la novela inglesa, a pesar de que parte de la critica especializada no haya reconocido su valor pionero. Entre quienes han dedicado un espacio destacable a LoveLetters se debe citar a Michael McKeon (2005, 506-546) que dedica todo el capitulo undecimo de The Secret History of Domesticity, publicado en 2005, a la obra epistolar behniana; tambien hay que mencionar a Brean Hammond and Shaun Regan (2006: 32-37) que dedican unas seis paginas de su Making the Novel. Fiction and Society in Britain, 1660-1789 a los libros de cartas de la escritora profesional.

\section{El contexto}

El relato de Love-Letters versa sobre un hombre casado que corteja a una mujer casada que, ademas, es su cufiada. La obra esta compuesta por un intercambio de cartas entre Silvia y su cufiado Philander de quien la protagonista se ha enamorado.

Aphra Behn escribio una novella titulada Oroonoko; or, The Royal Slave, que es su obra narrativa mas estudiada, a la que se le han dedicado incluso estudios monograficos como el libro editado por Cynthia Richards y Mary Ann O'Donnell (2014). Los relatos breves ocupan un lugar preeminente en la herencia literaria de Behn ya que se trata de pequefias ficciones cuya prosa brilla con luz propia, como The Fair Jilt, The Dumb Virgin; or The Force of Imagination or The Unfortunate Happy Lady.

El trabajo de ficcion mas voluminoso es precisamente el que da titulo a este articulo y destaca por contener una mezcolanza de historia, political propaganda, journalism, letters, farce and romance. Love-Letters between a Nobleman and his Sister, segun expresa Janet Todd (1996: ix) es un "huge work [...] issued anonymously in three parts and running to over one thousand pages" concretando que "it was the first published prose fiction of the Restoration 
playwright Aphra Behn"1. La obra refleja un eco de la caracterizacion pastoril y, en este sentido, opera de manera similar que en algunos poemas de Behn, como es el caso de "Dissapointment" donde las arboledas y la construction de los nombres propios presentan un reflejo de la poesia bucolica. Asimismo, esta pieza de ficcion destaca por tratar la naturaleza del amor, un asunto que

\section{El contexto}

El relato de Love-Letters versa sobre un hombre casado que corteja a una mujer casada que, además, es su cuñada. La obra está compuesta por un intercambio de cartas entre Silvia y su cuñado Philander de quien la protagonista se ha enamorado.

Aphra Behn escribió una novella titulada Oroonoko; or, The Royal Slave, que es su obra narrativa más estudiada, a la que se le han dedicado incluso estudios monográficos como el libro editado por Cynthia Richards y Mary Ann O’Donnell (2014). Los relatos breves ocupan un lugar preeminente en la herencia literaria de Behn ya que se trata de pequeñas ficciones cuya prosa brilla con luz propia, como The Fair Jilt, The Dumb Virgin; or The Force of Imagination or The Unfortunate Happy Lady.

El trabajo de ficción más voluminoso es precisamente el que da título a este artículo y destaca por contener una mezcolanza de historia, political propaganda, journalism, letters, farce and romance. Love-Letters between a Nobleman and his Sister, según expresa Janet Todd (1996: ix) es un "huge work [...] issued anonymously in three parts and running to over one thousand pages" concretando que "it was the first published prose fiction of the Restoration playwright Aphra Behn"1. La obra refleja un eco de la caracterización pastoril y, en este sentido, opera de manera similar que en algunos poemas de Behn, como es el caso de "Dissapointment" donde las arboledas y la construcción de los nombres propios presentan un reflejo de la poesía bucólica. Asimismo, esta pieza de ficción destaca por tratar la naturaleza del amor, un asunto que también aparece en primer plano tanto en la obra poética de la escritora como en los relatos breves. Como conclusión, se puede hablar de unidad temática, además de unidad de estilo y de modo compositivo.

\section{El contenido}

El contenido es definido por Todd (1996: xvii) como "sexual and state politics" matizando que "in politics the libertine creed tended towards the position [...] outlined by Thomas Hobbes in Leviathan (1651)", concretamente en el capítulo sexto, cuando establece que "whatsoever is the object of any man's appetite or desire, that is it which he for his part calleth good". Añade Todd que "Philander seems to follow this dictum". Precisamente el detonante del argumento es un escándalo social que ocurrió en 1682 y que terminó en juicio el 23 de noviembre de 1682; por lo que se deduce que la obra está basada en hechos históricos, concretamente en un episodio sobre un grupo de enemigos (Whig) del rey Carlos II que recogieron los periódicos de la época. Lord Grey of Werke (Ford) sedujo a su cuñada Lady Henrietta Berkeley y se fugaron. En septiembre de 1682, Lord Berkeley (el padre de Henrietta) llegó a anunciar en London Gazette una recompensa de 200 libras para quien ofreciera información sobre el paradero de su hija. En el universo literario, Lady Henrietta Berkeley es Silvia; James Scott (Duke of Monmouth) es

\footnotetext{
${ }^{1}$ J.Todd, Introduction to Aphra Behn, Love-Letters Between a Nobleman and His Sister, London: Penguin, 1996: ix-xxxiv.
} 
Caesario mientras que Lord Grey of Werke (Ford) es Philander. Mertilla es la esposa de Philander, que también es la hermana de Silvia.

El trasunto de la deslealtad estaba en el contexto sociopolítico de una época en la que se alzaban motines y revueltas, intrigas palatinas y complots de poder. Un ejemplo es el grupo de protestantes Whigs, incluyendo a Grey, que pretendían asesinar a Charles II y a su hermano el católico James Duke of York para entronizar a James Scott (Duke of Monmouth). En la misma órbita de la inestabilidad, se debe situar la indefinición de género que la obra presenta, o -dicho de otro modo- la convivencia de rasgos de diferentes géneros. Love-Letters encarna el desmantelamiento del romance, y el paso de la narración fantasiosa a una más realista, la transición del romance a los principios novelísticos, un aspecto que también destaca en Oroonoko; or The Royal Slave y evidencia la búsqueda de Behn por nuevas formas de expresión, tal como hemos estudiado a propósito de relatos breves como The Unfortunate Bride.

\section{Primera parte}

La "Part I" se centra en la fase del cortejo entre los dos amantes y culmina con la huida de su casa. Es un intercambio de cartas entre un defensor del duque de Condé y una dama de una familia católica. Philander es el conspirador Whig mientras que Silvia es la heroína tory. Esta bifurcación en lo que atañe a los personajes refleja el lado político tory de la escritora. Esta parte fue aprobada para su publicación en octubre de 1683 y fue publicada por Randal Taylor en 1684 . Está dedicada al capitán Thomas Condon, que se trata de un acérrimo defensor del duque de York.

El empleo de la técnica epistolar merece una mención porque se trata de un modo escritural todavía no muy utilizado en la literatura inglesa. El trabajo de Behn sigue revela la influencia de Les Lettres Portugaises (1669), traducida al inglés en 1678 (por Robert L'Estrange) como Five Love-Letters from a Nun to a Cavalier. Otro antecedente es la obra del periodista Paolo Marana, L'Espion Turc (1684-1686), traducida al inglés en un solo tomo en 1687. Se debe citar que en Inglaterra emanó una pedagogía sobre la escritura de cartas el siglo anterior (Tavor, 2009: 105-140), particularmente en los manuales The Enemy of Idleness (de William Fulwood, en 1568) o The English Secretary (de Angel Day, en 1586). Esta tradición había sido explotada por escritores como Cicerón, Monte Cassino (ars dictaminis), Isócrates o Erasmo (Libellus de conscribendis epistolis).

El vehículo de comunicación epistolar permite "writing from the heart" y exponer los sentimientos y reflexiones de modo sincero y directo. El lector tiene acceso directo a la interioridad del personaje que escribe la carta. Este texto muestra cómo Philander expresa a Silvia su interés y sus decisiones para conquistarla:

every Sound that meets the sense, is thy proper Musik, oh Love! And every thing inspires thy dictates; the Winds a round me blow soft, and mixing with the wanton Boughs, continually play and Kiss; while those like a coy Maid in Love resist and comply by turns; they like a ravish vigorous Lover, rush on with a transported violence; rudely inbracing its Spring drest Mistress, ruffling her Native order, while the pretty Birds on the dancing Branches incessantly make Love;... no Parents checking their dear delights, no slavish Matrimonial tyes to restrain their Nobler flame. No spyes to interrupt their blest appointments, but every little Nest is free and open to receive the young fletch't Lover; every bough is conscious of their Passion, nor do the generous pair languish in tedious Ceremony, but meeting look, and like, and Love, imbrace with their wingy Arms, and salute with their little opening Bills². (II, 35).

\footnotetext{
${ }^{2}$ N. Amstrong, Desire and Domestic Fiction. A Political History of the Novel. Oxford: Oxford University Press.
} 
El predominio de imágenes naturales hace el texto entendible consiguiendo un contexto pastoril donde destaca la búsqueda de libertad de los personajes, el deseo de un amor natural liberado de cadenas opresoras sociales. Se pone de manifiesto también el vigor de los amantes que están libres, sin vínculos serviles como el matrimonio y sin el control paternal. Precisamente la obra persigue un amor libre y desprovisto de ataduras postizas y convencionales, rompiendo el contrato social (Amstrong, 1987: 7-36). Así se aprecia al final de la primera parte cuando emerge una retórica peculiar en la que Silvia emula el estilo familiar de Philander:

When a true view is taken of the Soul, when no base interest makes the hasty bargain, when no conveniency or design of drudge, or slave, shall find it necessary, when equal judgements meet that can esteem the blessings they possess, and distinguish the good of eithers love, and set a value on each others merits, and were both understand to take and pay; who find the beauty of each others minds, and rate 'em as they ought, whom not a formal ceremony binds (with which I've nought to do, but dully give a cold consenting affirmative) but well considered vows from soft inclining hearts, utter'd with love, with joy, with dear delight when Heaven is call'd to witness; she is thy Wife, Philander, He is my Husband, this is the match, this Heaven designs and means... ${ }^{3}$ (II, 112).

\section{Partes segunda y tercera}

La "Part II", publicada en 1685, está dedicada a Lemuel Kingdon, auditor de las cuentas del ejército. La escritora prefirió inventar nuevas intrigas e infidelidades en lugar de plasmar directamente la derrota de la facción de Monmouth, en la batalla de Sedgemor (Somerset) (6 e julio de 1685). En esta parte del relato, Silvia y Philander viajan a la Europa continental. En esta fase se complica la trama porque aparece un nuevo pretendiente de Silvia que es el noble holandés Octavio y se potencia la infedilidad de Philander con Calista. Un rasgo de humor aparece cuando aflora la relación familiar entre Calista y Octavio, que son hermanos.).Al final de la segunda carta a Octavio que detalla con detenimiento la posesión de los encantos de Calista, él comenta "I have sent you a Novel, instead of a Letter of my first most happy adventure" ${ }^{4}$ (II, 272). Esta declaración permite aludir a la citada inestabilidad de género y, al mismo tiempo, a la conciencia auctorial de estar realizando una obra novedosa y pionera en la literatura inglesa.

La "Part III" es publicada en 1687, concretamente dos años después

de la ejecución de Monmouth que tuvo lugar el 15 de julio. Está dedicada a Robert Spencer (hijo de Sunderland), convertido al catolicismo. Este segmento de la obra realza la debilidad de los apoyos de Monmouth y muestra un desarrollo de Silvia como libertina mostrando en ocasiones el deseo equivalente a la perversidad.

\section{Hacia un nuevo stilo}

La claridad narrativa de la obra de Behn sigue los postulados de Francis Bacon (1605), en The Advancement of Learning (in Latin: Augmentis Scientarum), que condenaba el ciceronianismo criticando la exuberancia verbal. "This grew speedily to an excess for men began to hunt more after words than matter". Asimismo, Behn sigue el predicamento de John Beaumont (1629) en aras de un estilo simple, tal como anticipó en el poema "To His Late Majesty, Concerning the True Form of English Poetry". A mitad de siglo, Hobbbes en el capítulo tercero de Leviathan, a propósito de los nombres, deploró "the use of names that signify nothing" y abogó por "less in words and more in things", favoreciendo claramente res en relación a verba, dentro del binomio res-verba. En 1600, Jeremy Taylor (1660), en "Rules and Advices to the Clergy" aconsejaba que

\footnotetext{
${ }^{3}$ Ibidem.

${ }^{4}$ Ibidem
} 
los predicadores usaran "primitive, known, and accostumed words, and affect not the new fantastical, or schismatical terms". Siete años después, Abraham Cowley sigue el camino de Bacon y Hobbes y escribe "Ode to the Royal Society", en Thomas Sprat's History of the Royal Society, cuya estrofa cuarta indica que "From Words, which are but Pictures of the Thought / (Though we our Thoughts from them perversely drew) / To Things, the Mind's right Object, he is brought".

\section{Conclusión}

Toni Bowers and John Richetti (2011: 12) confirman la huella de Behn en Richardson cuando establecen que "an important popular precursor of Richardson's work [...] had been

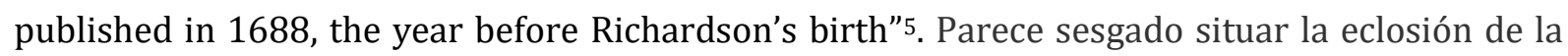
novela en obras como Clarissa y, por consiguiente, los estudiosos que así lo hacen resultan, además de injustos y parciales, incompletos en su abordaje. Por tanto, la narrativa epistolar de Aphra Behn tiene la primacía respecto a obras como Pamela o Julie, or la nouvelle Héloïse, lo cual es un hecho objetivo a nivel cronológico y también a nivel temático, retórico y estilístico.

Love-Letters between a Nobleman and his Sister tiene por derecho propio un sitio en el nacimiento de la novela en Inglaterra por lo que, con todas las matizaciones que se considere oportunas, la emergencia de la novela inglesa debe retrotraerse a estos años, antes de Robinson Crusoe (1719), Gulliver's Travels (1726) -para quienes consideran este libro como una novela- y, evidentemente, antes de Pamela; or, Virtue Rewarded (1740), Shamela (1741), Joseph Andrews (1742), Clarissa, or, the History of a Young Lady (1748).

Love-Letters Between a Nobleman and His Sister, 64 Years Before Clarissa, and the Nascent Genre of the English Novel

\section{Introduction}

The origins of the epistolary novel, as a genre, can be traced, in part, to Aphra Behn; specifically, in the years 1684, 1685 and 1687, when she published her three-part Love-Letters Between a Nobleman and His Sister. This study examines the role and value of the book as a watershed work by the English Restoration writer, preceding the famous works by Richardson, Montesquieu, Lacrosse, Goethe and Hölderlin.

Behn's narrative forms part of the foundational canon of the fictional tradition on adultery, and also constitutes a seminal work in the development of the English novel, even though many specialised critics have not acknowledged its value as a ground-breaking work. Among those who have devoted considerable attention to Love-Letters, mention should be made of Michael McKeon (2005, 506-546), who devotes an entire chapter (11) in his The Secret History of Domesticity, published in 2005, to Behn's epistolary work; as well as Brean Hammond and Shaun Regan (2006: 32-37), who dedicate six pages of their Making the Novel. Fiction and Society in Britain, 1660-1789 to the letter-based work penned by the female author.

\section{The context}

The plot of Love-Letters features a married man courting a married woman, who is also his sister-in-law. The work consists of an exchange of letters between Sylvia and her brother-in-law, Philander, with whom the female protagonist has fallen in love.

Aphra Behn wrote a novella entitled Oroonoko; or, The Royal Slave which is her most studied narrative work, the subject of monographic studies like the book edited by Cynthia

\footnotetext{
${ }^{5}$ T. Bowers, J. Richetti, "Introduction" to Samuel Richardon, Clarissa: or, The History of a Young Lady (Abridged Edition), Peterborough: Broadview Press, 2011, 12.
} 
Richards and Mary Ann O'Donnell (2014). Short stories occupy a prominent place in Behn's literary legacy, small works of fiction whose prose truly shines, as in The Fair Jilt, The Dumb Virgin; or The Force of Imagination and The Unfortunate Happy Lady.

Her most voluminous work of fiction is precisely that appearing in this article's title, and stands out as a work containing a curious mélange of history, political propaganda, journalism, letters, farce and romance. Love-Letters Between a Nobleman and His Sister, was described by Janet Todd (1996: ix) as a "huge work [...] issued anonymously in three parts and running to over one thousand pages," specifying that "it was the first published prose fiction of the Restoration playwright Aphra Behn". The work contains echoes of the pastoral genre and, in this regard, mirrors some of Behn's poetry, as in the case of "Disappointment", in which the groves described and the construction of proper names are characteristic of bucolic poetry. In addition, this piece of fiction is notable for the way it addresses the nature of love, a theme that also figures prominently in the author's poetic work and short stories. In conclusion, one can speak here of thematic unity, in addition to a common style and compositional approach.

\section{The content}

The content is defined by Todd (1996: xvii) as "sexual and state politics", with the qualification that "in politics the libertine creed tended towards the position [...] outlined by Thomas Hobbes in Leviathan (1651)", specifically in Chapter 6, in which the author states that "whatsoever is the object of any man's appetite or desire, that is it which he for his part calleth good". Todd adds that "Philander seems to follow this dictum." The crux of the plot is, precisely, a social scandal that erupted in 1682, ending with a trial on 23 November, 1682. Hence, it has been deduced that the work is actually based on real events involving a group of (Whig) enemies of King Charles II, covered by newspapers of the era. Lord Grey of Werke (Ford) seduced his sister-in-law, Lady Henrietta Berkeley, and they ran off. In September of 1682 Lord Berkeley (Henrietta's father) even posted a 200-pound reward in the London Gazette to anyone coming forward with information about his daughter's whereabouts. In the literary world, Lady Henrietta Berkeley is Silvia; James Scott (Duke of Monmouth) is Caesario, while Lord Grey of Werke (Ford) is Philander. Mertilla is Philander's wife, who is also Silvia's sister.

The question of disloyalty was present in the socio-political context of a time marked by riots and revolts, palace intrigues and plots for power. An example is the group of Protestant Whigs, including Grey, who sought to assassinate Charles II and his brother, the Catholic James Duke of York, and place James Scott (Duke of Monmouth) on the throne. The work's ambiguous genre rests along the same lines of instability, comprehending features from a range of different genres. Love-Letters embodies the dismantling of romance, and the shift from a fanciful class of narrative to a more realistic one, and the transition from romance to novelistic principles, an aspect that also stands out in Oroonoko; or The Royal Slave and evidences Behn's search for new forms of expression, as we have studied in short stories like The Unfortunate Bride.

\section{First part}

"Part I" focuses on the phase of courtship between the two lovers, and culminates with their flight from home. It is an exchange of letters between a supporter of the Duke of Condé and a lady from a Catholic family. Philander is the Whig conspirator, while Silvia is the Tory heroine. This bifurcation of the characters reflects the writer's pro-Tory political sympathies. This part was licensed in October of 1683 and was published by Randal Taylor in 1684. It is dedicated to Thomas Condon, a young captain and ardent supporter of the Duke of York. 
The use of the epistolary technique merits mention, because it represents a mode of writing not widely employed in English literature. Behn's work reveals the influence of Les Lettres Portugaises (1669), translated into English in 1678 (by Robert L'Estrange) as Five LoveLetters from a Nun to a Cavalier. Another precursor is the work by the journalist Paolo Marana, L'Espion Turc (1684-1686), translated into English in one volume in 1687. It should be noted that during the previous century there was a pedagogical movement centring on letter writing (Tavor, 2009: 105-140), particularly in the manuals The Enemy of Idleness (by William Fulwood, in 1568) and The English Secretary (by Angel Day, in 1586). This tradition had been exploited by writers like Cicero, Monte Cassino (ars dictaminis), Isocrates and Erasmus (Libellus de conscribendis epistolis).

Epistolary communication, as a vehicle, makes it possible to "write from the heart" and expose feelings and thoughts in an honest and direct way. The reader has direct access to the heart and mind of the character who writes the letter. In this text Philander expresses to Silvia his interest and decisions to seduce her:

every Sound that meets the sense, is thy proper Musik, oh Love! And every thing inspires thy dictates; the Winds a round me blow soft, and mixing with the wanton Boughs, continually play and Kiss; while those like a coy Maid in Love resist and comply by turns; they like a ravish vigorous Lover, rush on with a transported violence; rudely inbracing its Spring drest Mistress, ruffling her Native order, while the pretty Birds on the dancing Branches incessantly make Love;... no Parents checking their dear delights, no slavish Matrimonial tyes to restrain their Nobler flame. No spyes to interrupt their blest appointments, but every little Nest d Love, imbrace with their wingy Arms, and salute with their little opening Bills. (II, 35)is free and open to receive the young fletch't Lover; every bough is conscious of their Passion, nor do the generous pair languish in tedious Ceremony, but meeting look, and like, and Love, imbrace with their wingy Arms, and salute with their little opening Bills ${ }^{6}$. (II, 35).

The predominance of natural images makes the text comprehensible, producing a pastoral context portraying the characters' quest for freedom and their yearning for a natural love, liberated from oppressive social networks. It also depicts the vigour of lovers who are free, not burdened by slavish ties, like marriage, and unfettered by parental control. The work explicitly espouses a kind of free love, devoid of false and conventional bonds, breaking the social contract (Amstrong, 1987: 7-36). This can be appreciated at the end of the first part, in a peculiar section of rhetoric in which Silvia emulates Philander's familiar style:

When a true view is taken of the Soul, when no base interest makes the hasty bargain, when no conveniency or design of drudge, or slave, shall find it necessary, when equal judgements meet that can esteem the blessings they possess, and distinguish the good of eithers love, and set a value on each others merits, and were both understand to take and pay; who find the beauty of each others minds, and rate 'em as they ought, whom not a formal ceremony binds (with which I've nought to do, but dully give a cold consenting affirmative) but well considered vows from soft inclining hearts, utter'd with love, with joy, with dear delight when Heaven is call'd to witness; she is thy Wife, Philander, He is my Husband, this is the match, this Heaven designs and means... (II, 112).

\section{Second and third parts}

"Part II", published in 1685, is dedicated to Lemuel Kingdon, who is a Paymaster-general to the forces of Ireland. The writer chose to invent new intrigues and infidelities rather than directly

\footnotetext{
${ }^{6}$ N.Amstrong, Desire and Domestic Fiction. A Political History of the Novel. Oxford: Oxford University Press.
} 
depict the Monmouth faction's defeat at the Battle of Sedgemor (Somerset) (6, July, 1685). In this part of the story Silvia and Philander travel to continental Europe. During this phase the plot thickens, as there appears a new suitor for Sylvia, a Dutch nobleman named Octavio, and a spotlight is turned on Philander's infidelity with Calista. A touch of humour is included when the sibling relationship between Calista and Octavio is revealed.

At the end of her second letter to Octavio she states: "I have sent you a Novel, instead of a Letter of my first most happy adventure" (II, 272). This statement makes it possible to allude to the aforementioned instability of the genre and, at the same time, the author's consciousness of creating an innovative and pioneering work of English literature.

"Part III" was published in 1687, two years after Monmouth's execution on July 15. It is dedicated to Robert Spencer (Sunderland's son), a convert to Catholicism. This segment of the work focuses on the weakness of Monmouth's support, and in it Silvia is revealed as a libertine, at times evidencing a desire bordering on the perverse.

\section{Towards a new style}

The narrative clarity of Behn's work observes the tenets of Francis Bacon (1605), in The Advancement of Learning (in Latin: Augmentis Scientarum), which condemned Ciceronianism and criticised verbal exuberance. "This grew speedily to an excess for men began to hunt more after words than matter". Behn also follows the principles of John Beaumont (1629), embracing a simple style, as set forth in his poem "To His Late Majesty, Concerning the True Form of Poetry". In the middle of the century, Hobbes, in the third chapter of Leviathan, with regard to names, derided "the use of names that signify nothing" and called for "less in words and more in things", clearly favouring res over verba, with reference to the res/verba dichotomy. In 1661 Jeremy Taylor in Rules and Advice to the Clergy advised preachers to use "primitive, known, and accustomed words, and not the new fantastical, or schismatical terms". Seven years later, Abraham Cowley followed the path of Bacon and Hobbes and wrote "Ode to the Royal Society" in Thomas Sprat's History of the Royal Society, whose fourth stanza indicates that "From Words, which are but Pictures of the Thought / (Though we our Thoughts from them perversely drew) / To Things, the Mind's right Object, he is brought".

\section{Conclusion}

Toni Bowers and John Richetti (2011: 12) confirm Behn's literary influence on Richardson when they state that "an important popular precursor of Richardson's work [...] had been published in 1688, the year before Richardson's birth." It is biased to identify works like Clarissa as marking the advent of the novel, and those scholars who do so are being, in addition to unfair and partial, incomplete. Aphra Behn's epistolar narrative predates works like Pamela and Julie, and the nouvelle Héloïse, which is an objective fact at the chronological level, and also at the thematic, rhetorical and stylistic ones.

Love-Letters Between a Nobleman and His Sister merits its own prominent place in the genesis of the novel in England, such that, with all the qualifications that might be in order, the emergence of the English novel must be pushed back to the years before Robinson Crusoe (1719), Gulliver's Travels (1726) - for those who consider this book a novel - and, obviously, before Pamela; or, Virtue Rewarded (1740), Shamela (1741), Joseph Andrews (1742) Clarissa, or, the History of a Young Lady (1748). 


\section{Works cited}

Amstrong, Nancy, Desire and Domestic Fiction. A Political History of the Novel. Oxford: Oxford University Press, 1990.

Behn, Aphra, Love-Letters Between a Nobleman and His Sister, London: Penguin, 1996.

Bowers, Toni \& John Richetti, "Introduction" to Samuel Richardon, Clarissa: or, The History of a Young Lady (Abridged Edition), Peterborough: Broadview Press, 2011: 9-23.

Hammond, Brean \& Shaun Regan, Making the Novel. Fiction and Society in Britain, 1660-1789, New York: Macmillan, 2006.

McKeon, Michael, The Origins of the English Novel, 1600-1740, Baltimore: The John Hopkins University Press, 1986.

Tavor Bannet, Eve, Empire of Letters: Letter Manuals and Transatlantic Correspondence, 1680-1820, Cambridge: Cambridge University Press, 2009.

Todd, Janet, "Introduction" to Aphra Behn, Love-Letters Between a Nobleman and His Sister, London: Penguin, 1996: ix-xxxiv. 